\title{
School-leavers between education and the labour market 2011. Facts and figures
}

Citation for published version (APA):

Meng, C. M., \& Verhagen, A. M. C. (2012). School-leavers between education and the labour market 2011. Facts and figures. ROA. ROA Fact Sheets No. 001E https://doi.org/10.26481/umarof.2012001E

Document status and date:

Published: 01/01/2012

DOI:

10.26481/umarof.2012001E

Document Version:

Publisher's PDF, also known as Version of record

\section{Please check the document version of this publication:}

- A submitted manuscript is the version of the article upon submission and before peer-review. There can be important differences between the submitted version and the official published version of record.

People interested in the research are advised to contact the author for the final version of the publication, or visit the DOI to the publisher's website.

- The final author version and the galley proof are versions of the publication after peer review.

- The final published version features the final layout of the paper including the volume, issue and page numbers.

Link to publication

\footnotetext{
General rights rights.

- You may freely distribute the URL identifying the publication in the public portal. please follow below link for the End User Agreement:

www.umlib.nl/taverne-license

Take down policy

If you believe that this document breaches copyright please contact us at:

repository@maastrichtuniversity.nl

providing details and we will investigate your claim.
}

Copyright and moral rights for the publications made accessible in the public portal are retained by the authors and/or other copyright owners and it is a condition of accessing publications that users recognise and abide by the legal requirements associated with these

- Users may download and print one copy of any publication from the public portal for the purpose of private study or research.

- You may not further distribute the material or use it for any profit-making activity or commercial gain

If the publication is distributed under the terms of Article $25 \mathrm{fa}$ of the Dutch Copyright Act, indicated by the "Taverne" license above, 
Dus Maastricht University in Learning!

Research Centre for Education and the Labour Market | ROA

\section{School-leavers between education and the labour market 2011 \\ Facts and figures}

\section{ROA Fact Sheet}

ROA-F-2012/1E

Researchcentrum voor Onderwijs en Arbeidsmarkt | ROA Research Centre For Education and the Labour Market / ROA 


\section{Introduction}

Every year, ROA carries out a survey among school-leavers on the transition from school to a subsequent course or to the labour market. This fact sheet presents the results of the survey completed by ROA at the end of 2011 among graduates from the 2009-20I0 school year, so approximately eighteen months after they had completed school. The results relate to almost the entire scope of secondary and tertiary education: Preparatory Vocational Secondary Education (PVSE), Secondary Vocational Education - Vocational Training (SVE-VT), Secondary Vocational Education - Day Release (SVE-DR), Senior General Secondary Education (SGSE), Pre-University Education (PUE) and Higher Vocational Education (HVE). ${ }^{\mathrm{I}, 2}$ Within SVE, a distinction is made between Levels $\mathrm{I}^{3}$ and 2 on the one hand, and Levels 3 and 4 on the other. The data in the fact sheet have been aggregated, but the annex also provides an overview of the figures for each education level differentiated by type of education. For the full results relating to 20II, please refer to the Dutch ROA report "Schoolverlaters tussen onderwijs en arbeidsmarkt 20II". A total of 8I,865 school-leavers and graduates were approached. The total response rate was $33 \%$.

\section{Preparation}

Table I shows to what extent schools succeeded in preparing students for a successful start on the labour market. Of all students who left school with a diploma, 39\% felt that the course that they had completed provided a good basis for entering the labour market. This percentage was lowest amongst PVSE school-leavers ${ }^{4}$ (I in 4 PVSE school-leavers with a diploma believed that their course constituted a good basis for entering the labour market) and the highest among the higher levels of DR (57\%). For VT, and in particular for $\mathrm{DR}$, school-leavers with a diploma at one of the higher levels more often felt that the course that they had completed provided a good basis for a start on the labour market than their colleagues at the lower levels did. In HVE, slightly less than half $(46 \%)$ of the students considered their course a good basis for a start on the labour market. As far as the individual education sectors are concerned, a striking fact is that qualified school-leavers in health care at the higher SVE levels more often consider the course that they have completed a good basis for entering the labour market, while school-leavers from DR Economics, and in particular from VT Economics, do not share this view.

I. PVSE equals the Dutch term VMBO, SVE-VT equals MBO-BOL, SVE-DR equals MBO-BBL, SGSE equals HAVO, PUE equals VWO and HVE equals HBO.

2. Considering that ROA no longer has the survey among university graduates under its own management, no results for university graduates are presented in this fact sheet.

3. Level I qualifies for further education but not for the labour market.

4. This is to be expected, since a PVSE diploma doesn't provide a basic qualification.
Table I also shows which part of the qualified school-leavers considered their course a good basis for further development of knowledge and skills during their careers. Unlike the question to what extent the course constitutes a good basis for a start on the labour market - the short-term objective in education - these figures say something about the longterm objective in education. Of the entire group of qualified school-leavers, $57 \%$ believes that the course taken constitutes a good basis for further development of knowledge and skills. The satisfaction of DR and HVE graduates with this long-term objective in education is slightly above average. With $64 \%$, satisfaction is highest among qualified schoolleavers from the higher DR levels. Qualified school-leavers from the health care sector across almost the entire width of the education spectrum are often satisfied about this too.

Table 1

Starting on the labour market and further development of knowledge and skills

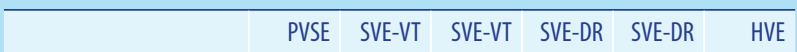

\begin{tabular}{|l|l|l|l|l|l|l|}
\hline & & $1 / 2$ & $3 / 4$ & $1 / 2$ & $3 / 4$ & \\
\hline $\begin{array}{l}\text { Course provides a good } \\
\text { basis for labour market } \\
\text { entry (\%) }\end{array}$ & 25 & 40 & 43 & 45 & 57 & 46 \\
$\begin{array}{l}\text { Course provides a } \\
\text { good basis for further } \\
\text { development of } \\
\text { knowledge and skills (\%) }\end{array}$ & 55 & 53 & 56 & 51 & 64 & 60 \\
\hline Source: ROA (SIS) & & & & & & \\
\hline
\end{tabular}

\section{Subsequent education}

After completing their studies, school-leavers may choose to either enter the labour market or continue their studies. Figure I gives an overview of the qualifying follow-up routes for the graduates from this survey. The figure lists for each type of education the percentage of graduates who entered a particular qualifying follow-up route since their graduation, as well as the percentage that did not opt for a qualifying follow-up route. For greater clarity, this figure combines the VT and DR levels, and only follow-up routes with a share of at least $5 \%$ have been listed.

From General Secondary Education (GSE) the majority goes on to take a subsequent course. 5 Of the entire group of SGSE respondents, $83 \%$ continued to do a HVE course. Of the PUE graduates, II\% went to do a HVE course, while the majority (77\%) opted for a University Education (UE) course. Of the qualified PVSE respondents, less than 5\% decided not to take a subsequent course. According to the figure, the percentage of PVSE school-leavers moving on to SGSE is less than $5 \%$. This may be a case of slight underestimation, because students who move from PVSE to SGSE within the same school may be a little less likely to respond than those who go to a different institute.

5. GSE equals the Dutch term AVO. 
Figure 1

Qualifying follow-up routes after leaving school

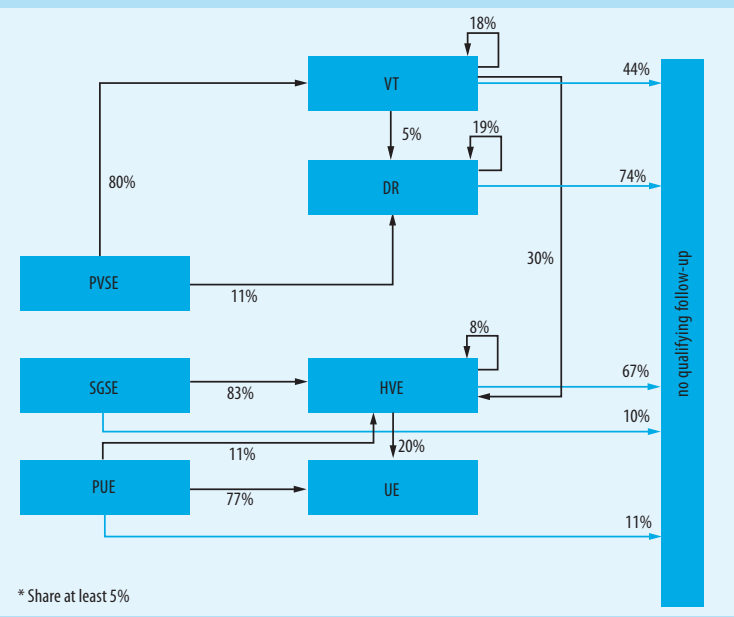

Source: ROA (SIS)

School-leavers who had moved on to a subsequent course, were asked what they thought of the match between the course that they had completed and the subsequent one. Figure 2 shows which part of the school-leavers who continued their studies considered this match sufficient or good. As the percentage of students from higher education who move on to regular subsequent courses is small and higher education does not primarily aim at follow-up education, HVE graduates were not asked this question. The vast majority of those who moved on to a subsequent course thought that the match between their previously completed course and the subsequent one was reasonable to good. Strikingly, in SVE-VT the judgment about the quality of the match clearly decreases as the education level increases. Whereas $78 \%$ of the SVE-VT graduates of Levels I and 2 are satisfied with the match, among SVE-VT graduates of the higher levels this is - on average - 'only' $61 \%$. This implies that almost $40 \%$ considers the match moderate to poor. In addition, graduates in the health care sector appeared quite satisfied with their match.

Figure 2

Percentage of school-leavers who continue their studies and who find the match between the course completed and the subsequent course sufficient or good

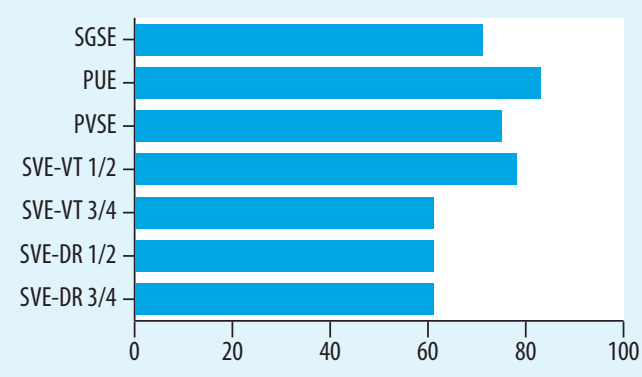

Source: ROA (SIS)

In addition to the total percentage of youngsters who leave the subsequent course prematurely, Figure 3 shows how many of them had left the subsequent course at the time of the survey without having started an alternative course (net dropouts) and how many of them switched courses. In total, $\mathrm{I} 2 \%$ of the school-leavers who moved on to another course indicated that they had stopped the initially chosen subsequent course at the time of the survey. Of all education levels, those who had dropped out of their subsequent courses were most likely to be found at SGSE or PUE level ( $17 \%$ and $15 \%$, respectively). School-leavers from lower levels within DR (3\%), on the other hand, were the least likely to have stopped their subsequent courses. For both learning routes within SVE, school-leavers at the higher levels were more likely to have dropped out of their subsequent courses than their colleagues at lower levels. Those who move on from HVE do better than average; of this group, 7\% terminates their subsequent course prematurely.

In reality, however, the percentage of dropouts shortly after having embarked on a subsequent course is less dramatic than may appear at first sight. What is perhaps more important than the total number of dropouts, is the percentage that does not embark on another course either. In other words, the net dropout percentage is more interesting than the gross dropout percentage. This prompts the question: What percentage of the dropouts are course switchers and what percentage has actually left the education system? Of the I $2 \%$ who moved on and stopped subsequent course prematurely, 8 percentage points switched courses. These youngsters therefore remain in the education system, but appear to have made the wrong choice initially. The remaining 4 percentage points are net dropouts. Similar figures can also be observed for those who move on from PVSE ( $7 \%$ course switchers and 3\% net dropouts). The majority of the relatively large percentage of SGSE graduate dropouts consists of course switchers (I4\%); the same goes for the PUE graduates who stopped (I4\%). This is offset by the - relatively small - group of SVE-DR school-leavers who leave their subsequent course prematurely and also leave the education system.

Figure 3

Percentage of those who left their subsequent course prematurely (net dropouts) and percentage of course switchers

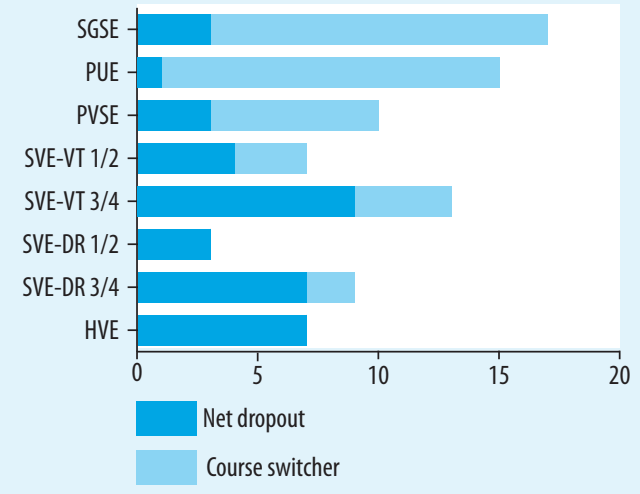

Source: ROA (SIS) 


\section{Labour market}

Instead of opting for a subsequent course, school-leavers also have the option of looking for a job and presenting themselves on the labour market. The youngsters on whom this fact sheet focuses, graduated in the 2009-20I0 school year. The majority of them completed their exams in the Spring/Summer of 20I0. Whereas the Dutch economy grew by some $2 \%$ at this time, the time of the survey (Autumn of 20II) coincided with a slight economic decline.

There are various indicators that show how smooth the transition between education and the labour market is for school-leavers. Firstly, we may look at the level of unemployment among school-leavers who enter the labour market (Figure 4). Total unemployment among school-leavers at the time of the survey was $7.4 \%$, which constitutes a one percentage point increase compared with the survey conducted in the Autumn of 20IO. The effects of the continuing economic crisis are mostly visible in the high unemployment rate among the lower educated. Among PVSE school-leavers, unemployment was I2\% (against 8\% in 20I0). Unemployment among VT school-leavers differs considerably between the lower and higher levels. Of all school-leavers at the two lower levels of SVE, no less than $20 \%$ is unemployed (against $16 \%$ in 20I0), whereas this applies to $8 \%$ (6\% in 20I0) of the school-leavers at the two higher levels. At DR level, there is less unemployment and the unemployment rates between school-leavers at the lower $(5 \%)$ and the higher (2\%) DR levels differ less. Also, there has not been a further increase in unemployment rates at this level since 20IO. The rounded unemployment rate among HVE graduates is $7 \%$ (6\% in 20I0). The data also show that unemployment among graduates in the economic sector across the entire education spectrum, is relatively high.

However, the unemployment rate at the time of the survey is not the only indicator of the smoothness of labour market entry. The same figure therefore also provides figures relating to the duration of the search for the first job. The figure indicates which part of the school-leavers was unemployed for 4 months or more before finding the first job. Qualified school-leavers from the lower two levels of SVE-VT (I3\%) and from HVE (I4\%) are generally the most likely ones to have to look for four or more months before finding their first job. For the latter group, this is not so surprising as the higher educated benefit from taking longer to find a suitable job. DR school-leavers need the least time for the search for their first job. Of those at the lower and higher DR levels, $4 \%$ and $2 \%$, respectively need four months or more to find their first job. This is undoubtedly related to the fact that the qualified school-leavers from SVE-DR often stay on with the employer where they did their training. Lastly, qualified school-leavers from both VT and DR need more time to find their first job as the level of the course completed is lower.
Figure 4

Unemployment among qualified school-leavers (\%)

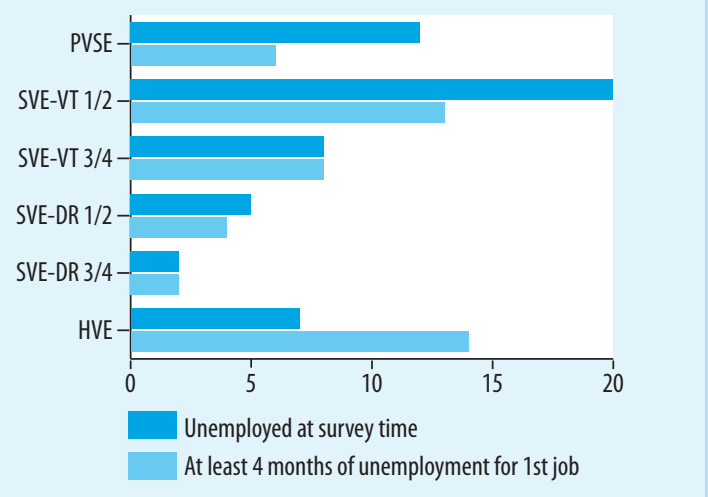

Source: ROA (SIS)

Figure 5 shows the unemployment developments for the various SVE levels and for HVE graduates. Unemployment having been relatively low in 2007 and 2008, there is a sometimes large - increase of unemployment at all education levels in 2009 due to the start of the economic crisis. In 2OIO, there is a stabilisation and partly (SVE-VT Levels 3/4) even a decrease. However, with the exception of SVE-DR, the situation worsened again in 20II. Since the survey in 2007, unemployment has increased considerably for most education levels: among HVE graduates from $3 \%$ to $7 \%$, among qualified school-leavers from VT Levels $3 / 4$ from $3 \%$ to $8 \%$, and among qualified school-leavers from VT Levels I $/ 2$ from $9 \%$ to $20 \%$.

Figure 5

Trends in unemployment by education level, 2008-2011

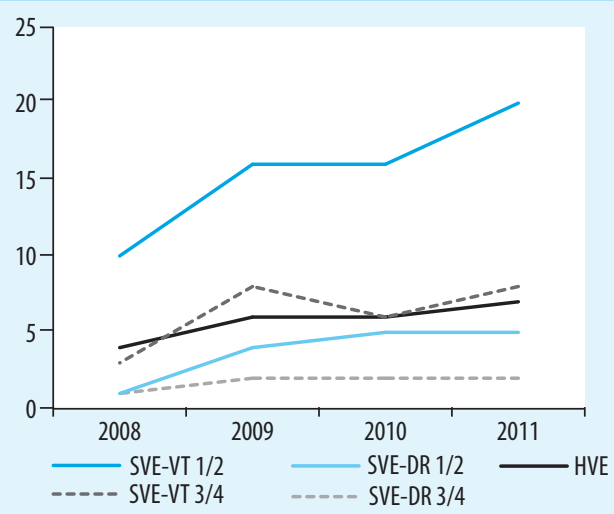

Source: ROA (SIS)

Figure 6 shows the unemployment rates for school-leavers by province. The province concerned is based on where the school-leavers live at the time of the survey. Unemployment is highest among school-leavers from Drenthe (I3\%), Friesland ( $13 \%$ ), Flevoland (I2\%) and Groningen (IO\%). As far as unemployment rates are concerned, schoolleavers were best off in $20 \mathrm{II}$ if they lived in the provinces of Overijssel, Gelderland, Utrecht, Zeeland or Noord-Brabant. In the latter provinces, unemployment rates among schoolleavers was only about $6 \%$. 
Figure 6

Unemployment rates by province

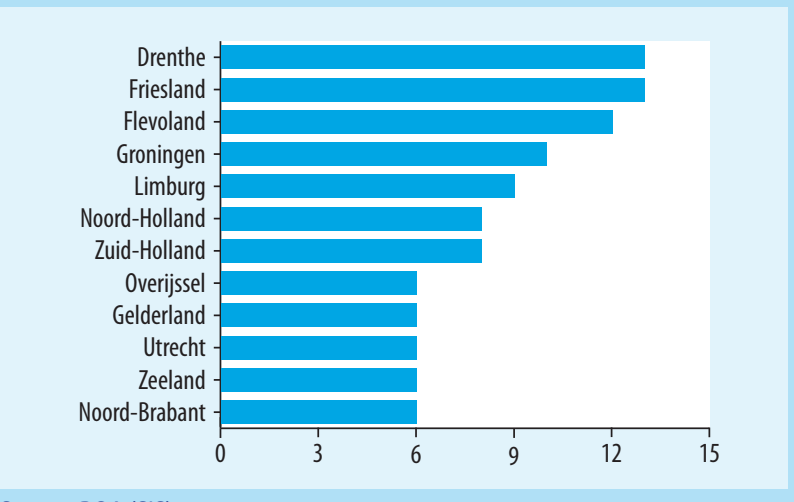

Source: ROA (SIS)

In addition to the unemployment rates, there are some other important indicators that illustrate the match between education and the labour market. Figure 7 shows how well the school-leavers' jobs match the course they completed in terms of level and type of course. Of all working schoolleavers, on average three quarters have a job that at least matches the level of their education. Of all working PVSE school-leavers, almost 8 out of Io said that they had a job that at least matched their education level. This can be explained by the fact that there are few jobs for which the required education level is lower than PVSE. Relatively many (80\%) qualified school-leavers from the higher VT levels also find a job that is at least at their own level. For both VT and DR, school-leavers from Levels I and 2 less often find a job at their own level than their colleagues from higher levels. Furthermore, almost 8 in every Io (78\%) HVE graduates have a job at least at their own level. Working school-leavers with a HVE diploma in Education very often have jobs at least at their own level, while on the other hand those with a HVE Behaviour \& Society diploma often work below their level. At SVE level, qualified school-leavers from the Health Care and Behaviour \& Society sectors relatively often work at least at their own level.

In addition to the level of the job, the type of job is also an important factor in determining the quality of employment. The survey therefore asked to indicate what - according to the employer - was the required type of education. The required type of education is an indicator for the degree to which someone works within the occupational domain for which he or she has been trained. Figure 7 shows that school-leavers from PVSE and VT Levels I and 2 are the least likely to work within their own occupational domain. Of these working school-leavers, between 60\% (PVSE) and 63\% (VT I/2) work in their own or a related domain. At the higher levels, $79 \%$ of the VT school-leavers work in their own occupational domain, while for DR school-leavers the percentage is even as high as $85 \%$. Of all HVE graduates, $78 \%$ work in their own or a related domain. Another fact that is worth mentioning is that school-leavers from the higher SVE levels in the Health Care and Behaviour \& Society sectors, often find a job that is related to their education. In HVE, this goes for graduates from the Education and Health Care sectors.
Figure 7

Percentage with a job at least at their own level, and percentage with a job in their own/related domain

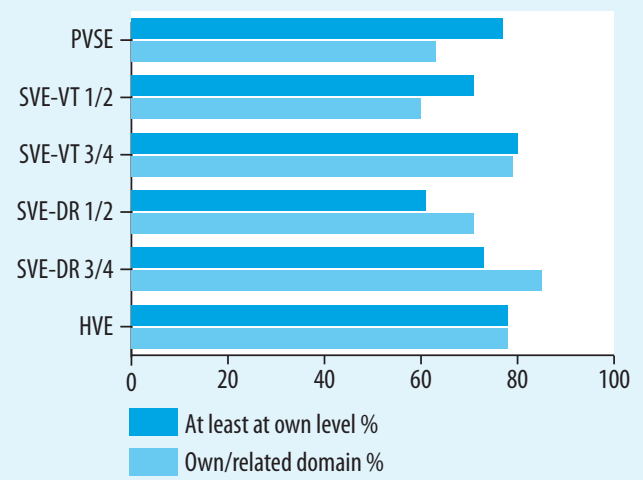

Source: ROA (SIS)

Respondents were also asked what they thought of the match between the course that they had completed and their present job. Figure 8 shows which part of the working school-leavers considered this match sufficient or good. With $85 \%$ and $77 \%$, respectively, qualified school-leavers from the higher and lower levels of DR are the ones who are most satisfied with this match. A possible explanation for this is the close relationship between education and the labour market in DR. In HVE, $74 \%$ of the working graduates thought that the match between education and work was sufficient or good. Although workers from the lower VT levels are the least satisfied with their match, 7 out of Io workers in this group still feel that the match between education and their present job was sufficient or good. Across the board, school-leavers from the Health Care sector are quite satisfied with the match between education and work.

\section{Figure 8}

Percentage that considers the match between education and work good or sufficient

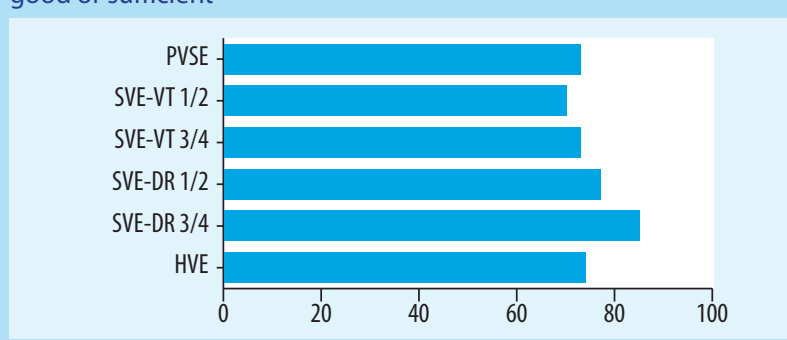

Source: ROA (SIS)

Another indicator for the quality of work and the transition from education to the labour marker, is the wages received by working school-leavers. Table 2 shows for each education level the average gross hourly wages. Hourly wages allow a better comparison than monthly wages, as differences in monthly wages can also be caused by the number of hours worked. As expected, average gross hourly wages increase with the education level. The average gross hourly wages for a working PVSE school-leaver are $€ 4.48$, which 
is again slightly lower than the year before $(€ 4.68)$. For qualified school-leavers of VT Levels I/2, hourly wages have remained constant at $€ 7.69$ since 20I0, whereas for schoolleavers of the higher VT levels, they have decreased slightly from €IO.37 to €IO.IO. For the other education levels, the average hourly wages have increased slightly compared with 20IO. Both for VT and for DR, hourly wages are higher as the level of the diploma is higher. DR school-leavers, on average, earn slightly more than their colleagues from VT, which may be explained from the fact that working DR school-leavers are, on average, slightly older than working VT school-leavers and often have a little more working experience. Average gross hourly wages among HVE graduates amount to $€ \mathrm{I} 3.38$, which is a slight decrease compared to the 20I0 survey.

For the individual education sectors, it is notable that graduates in the Health Care sector on average have relatively high gross hourly wages. However, because they more often work part time than other graduates, this does not necessarily mean that they have high gross monthly wages.

Table 2

Average gross hourly wages

\begin{tabular}{lcccccc}
\hline & PVSE & $\begin{array}{c}\text { SVE-VT } \\
1 / 2\end{array}$ & $\begin{array}{c}\text { SVE-VT } \\
3 / 4\end{array}$ & $\begin{array}{c}\text { SVE-DR } \\
1 / 2\end{array}$ & $\begin{array}{c}\text { SVE-DR } \\
3 / 4\end{array}$ & HVE \\
& & & & & & \\
\hline $\begin{array}{l}\text { Gross hourly wages } \\
\text { (in euros) }\end{array}$ & 4,48 & 7,69 & 10,10 & 10,42 & 12,73 & 13,38 \\
\hline
\end{tabular}

Source: ROA (SIS)

\section{Satisfaction with course (looking back)}

Figure 9 shows the percentage of qualified school-leavers who, looking back, would do the course that they had completed again. This only concerns SVE and HVE schoolleavers. The vast majority of the qualified school-leavers would again choose the course that they had completed again. DR school-leavers from the higher levels $(87 \%)$ were most likely to choose their own course again. But even among qualified PVSE school-leavers, who are the least likely to do the same course again, still 3 out of 4 said that they would choose the course that they had completed. School-leavers from the higher levels of VT, the lower levels of DR, as well as HVE, indicate in about 8 out of to cases that they would opt for the same course if they were to choose again.

\section{Figure 9}

Choose the same course again

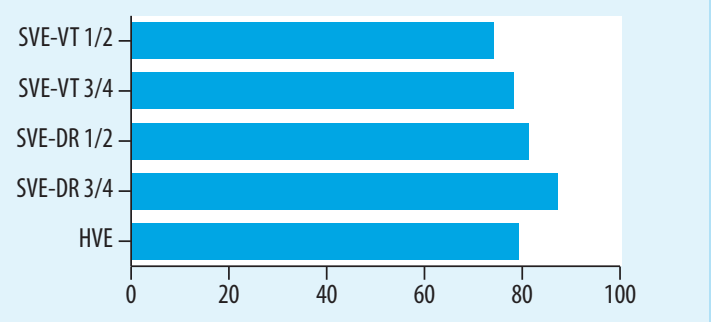

Source: ROA (SIS) 


\section{General}

\begin{tabular}{|c|c|c|c|}
\hline & $\begin{array}{l}\text { Course provides a good basis for } \\
\text { labour market entry (\%) }\end{array}$ & $\begin{array}{l}\text { Course provides a good basis for further } \\
\text { development of knowledge and skills (\%) }\end{array}$ & $\begin{array}{l}\text { Looking back, choose } \\
\text { course again (\%)PVSE }\end{array}$ \\
\hline PVSE & 25 & 55 & 88 \\
\hline PVSE theoretical programme & 19 & 56 & 91 \\
\hline PVSE Agriculture & 21 & 47 & 84 \\
\hline PVSE Technology & 34 & 61 & 90 \\
\hline PVSE Economics & 31 & 51 & 86 \\
\hline PVSE Health Care & 26 & 53 & 85 \\
\hline SVE & 46 & 56 & 80 \\
\hline VT & 42 & 55 & 77 \\
\hline VT 1 & 45 & 50 & 75 \\
\hline VT 2 & 39 & 54 & 74 \\
\hline VT 2 Agriculture & 50 & 68 & 78 \\
\hline VT 2 Technology & 34 & 56 & 75 \\
\hline VT 2 Economics & 34 & 46 & 67 \\
\hline VT 2 Health Care & 44 & 59 & 80 \\
\hline VT 3 & 44 & 56 & 76 \\
\hline VT 3 Agriculture & 25 & 33 & 73 \\
\hline VT 3 Technology & 35 & 43 & 76 \\
\hline VT 3 Economics & 38 & 52 & 70 \\
\hline VT 3 Health Care & 55 & 71 & 78 \\
\hline VT 3 Behaviour \& Society & 50 & 57 & 86 \\
\hline VT 4 & 42 & 56 & 79 \\
\hline VT 4 Agriculture & 34 & 48 & 74 \\
\hline VT 4 Technology & 41 & 54 & 80 \\
\hline VT 4 Economics & 39 & 55 & 76 \\
\hline VT 4 Health Care & 55 & 64 & 85 \\
\hline VT 4 Behaviour \& Society & 42 & 55 & 80 \\
\hline DR & 51 & 58 & 84 \\
\hline DR 1 & 32 & 41 & 78 \\
\hline DR2 & 49 & 54 & 82 \\
\hline DR 2 Agriculture & 49 & 51 & 86 \\
\hline DR 2 Technology & 51 & 54 & 85 \\
\hline DR 2 Economics & 41 & 48 & 74 \\
\hline DR 2 Health Care & 49 & 64 & 80 \\
\hline DR 3 & 58 & 64 & 88 \\
\hline DR 3 Agriculture & 53 & 60 & 87 \\
\hline DR 3 Technology & 56 & 62 & 85 \\
\hline DR 3 Economics & 42 & 54 & 88 \\
\hline DR 3 Health Care & 75 & 77 & 92 \\
\hline DR 3 Behaviour \& Society & 53 & 58 & 85 \\
\hline DR 4 & 56 & 65 & 85 \\
\hline DR 4 Agriculture & 46 & 61 & - \\
\hline DR 4 Technology & 52 & 63 & 86 \\
\hline DR 4 Economics & 47 & 58 & 86 \\
\hline DR 4 Health Care & 63 & 75 & 85 \\
\hline DR 4 Behaviour \& Society & 68 & 65 & 87 \\
\hline HVE & 46 & 60 & 79 \\
\hline HVE Agriculture & 52 & 67 & 77 \\
\hline HVE Technology & 57 & 66 & 86 \\
\hline HVE Economics & 45 & 60 & 72 \\
\hline
\end{tabular}




\section{General}

HVE Health Care

HVE Behaviour \& Society

HVE Education

HVE Language \& Culture

Total

Source: ROA (SIS)
Course provides a good basis for further

$$
\text { Course provides a good basis for }
$$

labour market entry (\%) development of knowledge and skills (\%)

62

57

54

65

57
Looking back, choose course again (\%)PVSE
52

39

85

85

84

86 


\section{Subsequent education}

\begin{tabular}{|c|c|c|c|}
\hline & $\begin{array}{c}\text { match } \\
\text { reasonable/good \% }\end{array}$ & $\begin{array}{l}\text { in subsequent } \\
\text { course } \%\end{array}$ & $\begin{array}{c}\text { Course switcher } \\
\text { in subsequent course \% }\end{array}$ \\
\hline SGSE/PUE & 76 & 2 & 14 \\
\hline SGSE & 71 & 3 & 14 \\
\hline PUE & 83 & 1 & 14 \\
\hline PVSE & 75 & 2 & 8 \\
\hline PVSE theoretical programme & 75 & 2 & 9 \\
\hline PVSE Agriculture & 73 & 3 & 5 \\
\hline PVSE Technology & 75 & 4 & 5 \\
\hline PVSE Economics & 76 & 3 & 9 \\
\hline PVSE Health Care & 75 & 4 & 6 \\
\hline SVE & 70 & 7 & 3 \\
\hline VT & 67 & 7 & 4 \\
\hline VT 1 & 84 & 4 & 2 \\
\hline VT 2 & 75 & 4 & 3 \\
\hline VT 2 Agriculture & 83 & 6 & 0 \\
\hline VT 2 Technology & 74 & 1 & 1 \\
\hline VT 2 Economics & 75 & 6 & 5 \\
\hline VT 2 Health Care & 76 & 5 & 2 \\
\hline VT 3 & 70 & 8 & 2 \\
\hline VT 3 Agriculture & 63 & 19 & 0 \\
\hline VT 3 Economics & 68 & 6 & 3 \\
\hline VT 3 Health Care & 76 & 7 & 1 \\
\hline VT 3 Behaviour \& Society & 73 & 13 & 3 \\
\hline VT 4 & 59 & 9 & 5 \\
\hline VT 4 Agriculture & 57 & 11 & 7 \\
\hline VT 4 Technology & 59 & 8 & 4 \\
\hline VT 4 Economics & 59 & 7 & 5 \\
\hline VT 4 Health Care & 60 & 7 & 3 \\
\hline VT 4 Behaviour \& Society & 60 & 13 & 6 \\
\hline DR 1 & 90 & 3 & 0 \\
\hline DR 2 & 82 & 3 & 0 \\
\hline DR 3 & 79 & 7 & 0 \\
\hline DR 4 & 67 & 6 & 6 \\
\hline HVE & - & 7 & 0 \\
\hline HVE Agriculture & - & 6 & 0 \\
\hline HVE Technology & - & 8 & 1 \\
\hline HVE Economics & - & 7 & 1 \\
\hline HVE Health Care & - & 4 & 0 \\
\hline HVE Behaviour \& Society & - & 6 & 1 \\
\hline HVE Education & - & 7 & 0 \\
\hline HVE Language \& Culture & - & 8 & 0 \\
\hline Source: ROA (SIS) & & & \\
\hline
\end{tabular}




\section{Labour market}

\begin{tabular}{|c|c|c|c|c|c|c|}
\hline & $\begin{array}{l}\text { At least at own } \\
\text { level } \%\end{array}$ & $\begin{array}{c}\text { Own/related } \\
\text { domain } \%\end{array}$ & $\begin{array}{c}\text { Match } \\
\text { sufficient/good \% }\end{array}$ & $\begin{array}{l}\text { Unemployed } \\
\%\end{array}$ & $\begin{array}{l}\text { Entry unemployment } \\
\qquad>3 \text { months } \%\end{array}$ & $\begin{array}{c}\text { Gross hourly wages } \\
\text { euros }\end{array}$ \\
\hline PVSE & 76 & 63 & 74 & 12 & 6 & 4,48 \\
\hline PVSE theoretical programme & 70 & 51 & 60 & 22 & 6 & 4,55 \\
\hline PVSE Agriculture & 71 & 56 & 73 & 7 & 7 & 4,30 \\
\hline PVSE Technology & 86 & 74 & 85 & 7 & 4 & 4,82 \\
\hline PVSE Economics & 76 & 55 & 74 & 12 & 11 & 3,95 \\
\hline PVSE Health Care & 69 & 66 & 62 & 10 & 6 & 4,31 \\
\hline SVE & 72 & 77 & 78 & 7 & 7 & 10,79 \\
\hline VT & 78 & 74 & 73 & 11 & 10 & 9,55 \\
\hline VT 1 & 74 & 59 & 73 & 35 & 17 & 6,72 \\
\hline VT 2 & 71 & 61 & 69 & 17 & 12 & 7,89 \\
\hline VT 2 Agriculture & 61 & 69 & 51 & 19 & 12 & 6,55 \\
\hline VT 2 Technology & 68 & 48 & 57 & 13 & 10 & 8,69 \\
\hline VT 2 Economics & 63 & 56 & 70 & 17 & 17 & 7,62 \\
\hline VT 2 Health Care & 84 & 76 & 78 & 18 & 9 & 7,89 \\
\hline VT 3 & 76 & 75 & 76 & 10 & 8 & 9,57 \\
\hline VT 3 Agriculture & 73 & 73 & 62 & 10 & 21 & 8,37 \\
\hline VT 3 Technology & 84 & 80 & 76 & 4 & 12 & 8,84 \\
\hline VT 3 Economics & 62 & 61 & 71 & 16 & 12 & 8,54 \\
\hline VT 3 Health Care & 79 & 81 & 78 & 2 & 5 & 9,78 \\
\hline VT 3 Behaviour \& Society & 86 & 84 & 81 & 11 & 6 & 11,18 \\
\hline VT 4 & 82 & 80 & 73 & 7 & 7 & 10,35 \\
\hline VT 4 Agriculture & 68 & 76 & 65 & 8 & 7 & 9,52 \\
\hline VT 4 Technology & 77 & 82 & 66 & 7 & 7 & 10,48 \\
\hline VT 4 Economics & 80 & 71 & 73 & 9 & 8 & 9,21 \\
\hline VT 4 Health Care & 90 & 90 & 80 & 3 & 3 & 11,52 \\
\hline VT 4 Behaviour \& Society & 86 & 82 & 72 & 8 & 9 & 10,78 \\
\hline DR & 67 & 79 & 81 & 4 & 3 & 11,69 \\
\hline DR 1 & 40 & 58 & 71 & 8 & 3 & 10,13 \\
\hline DR2 & 65 & 74 & 79 & 5 & 5 & 10,50 \\
\hline DR 2 Agriculture & 67 & 73 & 82 & 2 & 5 & 9,39 \\
\hline DR 2 Technology & 66 & 78 & 77 & 4 & 6 & 10,36 \\
\hline DR 2 Economics & 54 & 50 & 75 & 7 & 3 & 10,63 \\
\hline DR 2 Health Care & 78 & 89 & 87 & 4 & 1 & 11,49 \\
\hline DR3 & 66 & 84 & 86 & 2 & 2 & 12,12 \\
\hline DR 3 Agriculture & 60 & 92 & 76 & 3 & 0 & 10,91 \\
\hline DR 3 Technology & 54 & 84 & 87 & 3 & 2 & 12,66 \\
\hline DR 3 Economics & 58 & 65 & 78 & 1 & 2 & 10,40 \\
\hline DR 3 Health Care & 80 & 93 & 95 & 0 & 2 & 12,69 \\
\hline DR 3 Behaviour \& Society & 93 & 94 & 89 & 3 & 2 & 12,89 \\
\hline
\end{tabular}




\section{Labour market}

\begin{tabular}{|c|c|c|c|c|c|c|}
\hline & $\begin{array}{l}\text { At least at own } \\
\quad \text { level \% }\end{array}$ & $\begin{array}{c}\text { Own/related } \\
\text { domain \% }\end{array}$ & $\begin{array}{c}\text { Match } \\
\text { sufficient/good \% }\end{array}$ & $\begin{array}{c}\text { Unemployed } \\
\%\end{array}$ & $\begin{array}{l}\text { Entry unemployment } \\
>3 \text { months } \%\end{array}$ & $\begin{array}{c}\text { Gross hourly wages } \\
\text { euros }\end{array}$ \\
\hline DR 4 & 87 & 87 & 81 & 3 & 2 & 13,72 \\
\hline DR 4 Technology & 81 & 90 & 91 & 0 & 2 & 15,25 \\
\hline DR 4 Economics & 80 & 74 & 80 & 6 & 2 & 12,45 \\
\hline DR 4 Health Care & 92 & 96 & 79 & 2 & 0 & 13,72 \\
\hline DR 4 Behaviour \& Society & 100 & 96 & 85 & 3 & 6 & 14,20 \\
\hline HVE & 78 & 78 & 74 & 7 & 14 & 13,38 \\
\hline HVE Agriculture & 74 & 72 & 73 & 8 & 13 & 12,57 \\
\hline HVE Technology & 87 & 86 & 77 & 4 & 13 & 14,05 \\
\hline HVE Economics & 78 & 65 & 69 & 8 & 16 & 13,35 \\
\hline HVE Health Care & 81 & 93 & 80 & 2 & 7 & 15,12 \\
\hline HVE Behaviour \& Society & 55 & 85 & 70 & 7 & 17 & 13,36 \\
\hline HVE Education & 92 & 92 & 85 & 6 & 10 & 13,57 \\
\hline HVE Language \& Culture & 68 & 62 & 68 & 9 & 16 & 9,16 \\
\hline Total & 73 & 75 & 76 & 7 & 8 & 10,54 \\
\hline
\end{tabular}

Source: ROA (SIS) 


\section{Unemployment trend}

\begin{tabular}{|c|c|c|c|c|c|c|c|c|c|c|c|}
\hline & 2001 & 2002 & 2003 & 2004 & 2005 & 2006 & 2007 & 2008 & 2009 & 2010 & 2011 \\
\hline SGSE & 2 & 8 & 17 & 18 & 19 & 11 & 17 & 17 & 19 & 15 & 9 \\
\hline PUE & 6 & 4 & 13 & 15 & 19 & 5 & 23 & 11 & 12 & 18 & 9 \\
\hline PVSE & 6 & 3 & 7 & 6 & 12 & 6 & 6 & 9 & 6 & 8 & 12 \\
\hline SVE-VT $1 / 2$ & 7 & 8 & 16 & 25 & 21 & 13 & 9 & 10 & 16 & 16 & 20 \\
\hline SVE-VT $3 / 4$ & 2 & 4 & 4 & 11 & 8 & 6 & 3 & 3 & 8 & 6 & 8 \\
\hline SVE-DR $1 / 2$ & - & - & - & - & - & - & 3 & 1 & 4 & 5 & 5 \\
\hline SVE-DR $3 / 4$ & - & - & - & - & - & - & 1 & 1 & 2 & 2 & 2 \\
\hline HVE & 3 & 3 & 6 & 6 & 5 & 5 & 3 & 4 & 6 & 6 & 7 \\
\hline
\end{tabular}

- Not available

Note: In the 2000 - 2002 surveys, this concerns Lower Secondary General Education (LGSE)/Initial Professional Education (IPE) school-leavers. From the 2003 survey onwards, these are PVSE school-leavers.

Comment: The year is the year of the survey. In 2011, respondents came from the 2009-2010 cohort. 


\section{Imprint}

(C) Research Centre for Education and the Labour Market (ROA). Nothing in this publication may be duplicated in any way without prior written permission from ROA's director.

Research Centre for Education and the Labour Market Maastricht University

School of Business and Economics secretary-roa-sbe@maastrichtuniversity.nl www.roa.nl

\section{Layout}

ROA Secretariat, Maastricht

August 2012 
Researchcentre for Education and the Labour Market

P.O. Box 616

6200 MD Maastricht

The Netherlands

$\mathrm{T}+31433883647$

$\mathrm{F}+31433884914$

secretary-roa-sbe@maastrichtuniversity.n

www.roa.nl

Maastricht University

School of Business and Economics 